\title{
"If it did not exist, \\ it would have to be invented": \\ Home Economics in Transition at Iowa's Regents Institutions
}

\author{
GWEN KAY
}

IN THE 1980s, college home economics programs almost disappeared in Iowa. Ironically, the first domestic science course in the nation was offered at Iowa State Agricultural College in 1871, long before the creation and codification of the discipline of home economics in 1908. For more than a century, home economics has survived, adapted, and even thrived at Iowa's statefunded institutions of higher education. In the 1980s, however, two decisions by the Board of Regents - one financial and one "social" - significantly affected home economics at the Regents institutions. How each school reacted to these external challenges, which were often coupled with internal pressures, is the subject of this article.

Ideally, we would give equal consideration to the home economics programs at the University of Iowa (UI), the University of Northern Iowa (UNI), and Iowa State University (ISU), the three Regents institutions in Iowa. Given the archival resources available, however, UNI, formerly Iowa State Teachers College, will appear only when all institutions are being evaluated by an

The research for this article was supported by a grant from the State Historical Society of Iowa. The author wishes to thank the anonymous reviewers for The Annals of Iowa, and especially Julia Faltinson Anderson and Frances Smith for their help and kindness.

THE ANNALS OF IOWA 70 (Spring 2011). (C) The State Historical Society of Iowa, 2011. 
outside entity. ISU, the sole land-grant institution, fared exceptionally well in the outside evaluation. At the time of these challenges, the home economics department at UI was in the weakest position of the three schools, and it reacted strongly to external reports suggesting its demise.

HIGHER EDUCATION has meant different things in different states. In the Northeast in the late nineteenth century, many small, private, single-sex, liberal arts colleges were established, while in the Midwest publicly funded institutions were more dominant. ${ }^{1}$ Iowa, as a representative state, has a mix of public and private colleges and universities. One financial incentive spurring public higher education nationally was the Morrill Land Grant Act of 1862, which emphasized education in each state to enhance the lives of its residents, male and female. This led to the peculiar situation in which a state might have multiple state-funded universities but only one land-grant institution, typically with an emphasis on agriculture and mechanical arts. ${ }^{2}$ In Iowa, ISU is the land-grant institution. UNI, however, benefited from another piece of federal legislation, the 1917 SmithHughes Vocational Act, which provided federal funding for institutions specifically training teachers in vocational arts (including home economics). ${ }^{3}$

One dilemma facing land-grant and state-funded schools was what to teach women. ${ }^{4}$ Educating future teachers - the

1. On higher education, see John R. Thelin, A History of American Higher Education (Baltimore, 2004); and Claudia Goldin, The Shaping of Higher Education: The Formative Years in the United States, 1890-1940 (Cambridge, MA, 1998).

2. An Early View of the Land-Grant Colleges: Convention of Friends of Agricultural Education in 1871 (1871; reprint, Urbana, IL, 1967).

3. Congress passed the Smith-Hughes Act in 1917; in 1919 Iowa State Teachers College was approved for teacher training under the act. Ercel Sherman Eppright and Elizabeth Storm Ferguson, A Century of Home Economics at Iowa State University (Ames, 1971), 73.

4. On women's higher education and the debates about appropriate education for women, see Kim Tolley, The Science Education of American Girls: A Historical Perspective (New York, 2003); Amy Thompson McCandless, The Past in the Present: Women's Higher Education in the Twentieth-Century American South (Tuscaloosa, AL, 1999); Irene Harwarth, Mindi Maline, and Elizabeth DeBra, Women's Colleges in the United States: History, Issues, and Challenges (Washington, DC, 1997); Helen Lefkowitz Horowitz, Alma Mater: Design and Experience in the Women's 
function of a "normal school" — was one possibility, and UNI filled this niche. ${ }^{5}$ Other career-oriented educational programs included those for social work and nursing. ${ }^{6}$ As scholars have demonstrated, those fields gendered female have had lower status, which translated into lower pay for those employed in those areas; such fields also found less support and more vulnerability on college campuses compared with support for nonor male-gendered fields, such as biology or agricultural science.

There was another educational option for women: courses in domestic science, following the early success at ISU. In 1898 Ellen Swallow Richards, a chemist teaching "ladies courses" at MIT, aided by Melvil Dewey, librarian for the State of New York, organized a conference of like-minded women and men to discuss education, science, and women and ways to organize and combine these seemingly disparate topics. ${ }^{7}$ The group met annually for ten years at the Lake Placid Club. During that time they created a new discipline: home economics. ${ }^{8}$ Although they

Colleges from their Nineteenth-Century Beginnings to the 1930s, 2nd ed. (Amherst, MA, 1993); and Barbara Miller Solomon, In the Company of Educated Women: A History of Women and Higher Education in America (New Haven, CT, 1985).

5. Christine A. Ogren, The American State Normal School: An Instrument of Great Good (New York, 2005).

6. On nursing, see Patricia D'Antonio, American Nursing: A History of Knowledge, Authority, and the Meaning of Work (Baltimore, 2010); Susan Gelfand Malka, Daring to Care: American Nursing and Second-Wave Feminism (Urbana, IL, 2007); Darlene Clark Hine, Black Women in White: Racial Conflict and Cooperation in the Nursing Profession, 1890-1950 (Bloomington, IN, 1989); and Susan M. Reverby, Ordered to Care: The Dilemma of American Nursing, 1850-1945 (New York, 1987). On social work, see Daniel J. Walkowitz, Working with Class: Social Workers and the Politics of Middle-Class Identity (Chapel Hill, NC, 1999); Karen W. Tice, Tales of Wayward Girls and Immoral Women: Case Records and the Professionalization of Social Work (Urbana, IL, 1998); and Robyn Muncy, Creating a Female Dominion in American Reform, 1890-1935 (New York, 1991).

7. On Richards, see Margaret W. Rossiter, Women Scientists in America: Struggles and Strategies to 1940 (Baltimore, 1982), esp. chaps. 3 and 4; Esther Douty, America's First Woman Chemist, Ellen Richards (New York, 1961); and Caroline L. Hunt, Life of Ellen H. Richards, 1842-1911 (Boston, 1912).

8. Lake Placid Conference on Home Economics: Conference Proceedings, vols. 1-10 (1899-1908). For analysis of the conference and the early years of home economics, see Emma Seifrit Weigley, "It Might Have Been Euthenics: The Lake Placid Conferences and the Home Economics Movement," American Quarterly 26 (1974), 79-96; and two internally produced histories: Helen Pundt, AHEA: $A$ History of Excellence (Washington, DC, 1980); and Keturah E. Baldwin, The AHEA Saga: A Brief History ... (Washington, DC, 1949). 
did not attend the conferences, several members of the group were from Iowa, including instructors from Iowa State College of Agriculture and Iowa State Teachers College, as well as one woman without an institution affiliation.

The annual meetings at Lake Placid culminated in 1908 with the creation of home economics as an academic discipline and an organization, the American Home Economics Association (AHEA), to help professionalize the nascent field. The women and men who were party to these discussions drew on a recent but rich history of women's education and proper role in society. Catherine Beecher, who in the mid-nineteenth century championed women's place in the home and elevated domesticity, wrote an advice manual with her sister, Harriet Beecher Stowe, to instruct women on how best to perform their domestic duties. ${ }^{10}$ For some, then, home economics provided a way to continue, or expand, in the more modern context of women's education, the role set forth by the Beechers. Historian Marilyn Holt suggests that

in the nineteenth century, a general attitude prevailed that females were born with natural instincts for motherhood and homemaking; these inherent qualities simply were reinforced from other females or printed materials. With the rise of progressive ideas and the science of domesticity, this attitude diminished. Any instincts a woman might have for domesticity, it was now thought, did not emerge naturally. Only structured education would instill the attitude and skills needed to maintain a home and family. Efficiency

9. Members of the Seventh and Eighth Lake Placid Conferences (1905 and 1906) included Grace McKibben (Memorial University) and Mary Rausch and Georgetta Witter (both Iowa State College of Agriculture). Members of the Ninth conference (1907) included Rausch and Mrs. Luke Mathes (Dubuque). Members of the Tenth conference (1908) included Mathes and Mary Townsend (Iowa State Teachers College). Lake Placid Conference Proceedings (1906), 158-59; ibid. (1906), 129-31; ibid. (1907), 162; ibid. (1908), 208-11. Although none of these women attended the conferences, they were members, likely received mailings, and could have worked on various committees.

10. For more on these domestic advice manuals, see Sarah A. Leavitt, From Catharine Beecher to Martha Stewart: A Cultural History of Domestic Advice (Chapel Hill, NC, 2002); Catherine E. Beecher and Harriet Beecher Stowe, The American Woman's Home, ed. Nicole Tonkovich (New Brunswick, NJ, 2002); Barbara Ehrenreich and Deirdre English, For Her Own Good: 150 Years of the Experts' Advice to Women (New York, 1978); and Kathryn Kish Sklar, Catharine Beecher: A Study in American Domesticity (New York, 1976). 
and the scientific approach were learned traits, not inherited female qualities. ${ }^{11}$

Home economics was both a product of and ahead of its time. In fashioning an education for women that was practical, applicable, and useful inside and outside the home, and in adapting the latest scientific discoveries for use in the home, it was a product of its time. ${ }^{12}$ The intent of Richards and her compatriots at Lake Placid was to interpret science in a meaningful way so that science could be translated into everyday use rather than remain a mere laboratory abstraction. In another way, however, home economics was ahead of its time, creating an interdisciplinary field that simultaneously used knowledge from a variety of scientific fields - including biology, chemistry, mathematics, physics, and physiology - to create a field with a multitude of professional opportunities that in later decades would include areas such as institutional or facilities management, dietetics, interior design, textiles, fashion merchandising, education, family counseling, extension services, and business. Although some people were uncomfortable with or suspicious of educating women in the sciences via home economics, the field garnered strong support. ${ }^{13}$ As Holt has argued, this reframing or

11. Marilyn Irvin Holt, Linoleum, Better Babies, E The Modern Farm Woman, 18901930 (Albuquerque, NM, 1995), 166.

12. For the ways home economics was employed in the context of domesticity, see Susan Strasser, Never Done: A History of American Housework (New York, 2000); Nancy Tomes, The Gospel of Germs: Men, Women and the Microbe in American Life (Cambridge, MA, 1998); Glenna Matthews, "Just a Housewife": The Rise and Fall of Domesticity in America (New York, 1987); and Ruth Schwartz Cowan, More Work for Mother: The Ironies of Household Technology from the Open Hearth to the Microwave (New York, 1983). For the early history of home economics, see Megan J. Elias, Stir It Up: Home Economics in American Culture (Philadelphia, 2008), 3-15, Sarah Stage, "Ellen Richards and the Social Significance of the Home Economics Movement," in Rethinking Home Economics: Women and the History of the Profession, ed. Sarah Stage and Virginia B. Vincenti (Ithaca, NY, 1997); Rima Apple, "Liberal Arts or Vocational Training? Home Economics Education for Girls," ibid.; Rossiter, Women Scientists to 1940, esp. 64-70; and Marie Negri Carver, Home Economics as an Academic Discipline: A Short History (Tucson, AZ, 1979).

13. Male students, faculty, and administrators may have been in the former camp, with clubwomen, female students, and faculty in the latter, but there were some exceptions. Liberty Hyde Bailey, dean of the New York State College of Agriculture at Cornell (1903-1913), was an ardent supporter of women's 
"application of scientific principles to homemaking" coincided with reform in American culture (particularly the Progressive movement); other cultural factors and federal funding complemented the home economics agenda. ${ }^{14}$

Iowa State College (ISC), Iowa State Teachers College (ISTC), and the State University of Iowa (SUI) each offered home economics as a course of study. At ISC, the earliest courses in domestic science were taught by the first president's wife, Mary Welch. Home economics, as the program became known, was one of the five colleges at ISC. ${ }^{15}$ Currently, Iowa State is the only institution in Iowa that grants a Ph.D. in this field. ${ }^{16}$ At ISTC, home economics, first introduced in 1913, fit within the curriculum for teachers education, so the initial thrust was home economics education. ISTC's strength was its strong regional draw. It created well-prepared teachers who hoped to return to their hometowns. At SUI, the state's oldest institution of higher education, liberal arts was the educational core. ${ }^{17}$ SUI perceived its mission differently than the other institutions and sought to offer a diverse educational experience to its students. Accordingly, home economics was a department at SUI within the College of Liberal Arts, as opposed to being its own college at it was at ISTC and ISC.

Herein lies an interesting difference: at both ISTC and ISC, home economics was a school (and subsequently a college) within the college (and subsequently university) system. By contrast, at SUI, home economics was a department within the Col-

education, particularly home economics. Over the course of the twentieth century, those in favor of and those opposed to home economics as a field of education, primarily for women, continued to maintain these positions.

14. Holt, Linoleum, Better Babies \& The Modern Farm Woman, 4.

15. The five original colleges of Iowa State College of Agriculture and Mechanical Arts were Veterinary Medicine, Engineering, Industrial Science, Home Economics, and Agriculture. For more on the home economics program, see Eppright and Ferguson, A Century of Home Economics at Iowa State University.

16. After ISTC became the University of Northern Iowa, it offered a Ph.D. in home economics until the Regents implemented the recommendations of the KPMG report. For more on this, see below.

17. American Home Economics Association (AHEA) Site Visit Report, 1983, p. 4, box 1, University of Iowa Department of Home Economics Records (hereafter cited as UI Home Ec Records), Iowa Women's Archives, University of Iowa Libraries, Iowa City (hereafter cited as IWA). 
lege of Liberal Arts, which rendered it less visible and less powerful and required it to do more to benefit other departments within its college. ${ }^{18}$ Also, despite overlap (especially with home economics education), the department was never located within the School of Education. Home economics at SUI was always an uneasy fit, housed at it was in a liberal arts college rather than in a college of agriculture or education. Without majors in agriculture, industrial arts, or forestry, a 1988 self-study noted, the department stood alone at the university in its goal "to enhance the quality of life through a program designed to develop a working understanding of family and individuals in their environment. Through study, understanding and use of various aspects of apparel, fiber art, design, and family science, [the department] contributes to the physical, psychological, social, economic and aesthetic development of people." ${ }^{19}$ This profession-oriented major was at odds with peer departments in its college.

An obvious question arises: why is there such duplication in one state? Why have three programs competing with each other for students, faculty, and resources within the same state, when one might suffice? One might easily pose the same question about duplication of other specialty departments. In 1912 the Iowa Board of Education (the forerunner of the Board of Regents) sought to do just that when they considered consolidating and avoiding unnecessary duplication of programs statewide. Toward that end, the board adopted a resolution to study whether it was feasible to move home economics from ISC to SUI,

18. The challenges that the UI department faced, especially when compared to those at its peer institutions, did not go unnoticed. A 1975 Report of the Committee for Review of the Department of Home Economics, conducted by five faculty on campus from outside the department and one external member (a former department member), noted that "since the Department here operates in the context of a Liberal Arts College, unlike the units of Iowa State University and University of Northern Iowa, its orientation is somewhat different from those of the other schools, and, being smaller, it can exercise greater curricular flexibility and innovation than they. There is more individualized instruction here, perhaps to the extent of demanding so much time that there is serious encroachment on the faculty's research effort." Self-Study and Departmental Analysis Report for Departmental Review, University of Iowa Department of Home Economics, 1975, box 3, UI Home Ec Records, IWA.

19. Interim Accreditation Report to the Council for Professional Development, AHEA, 1988, p. 4, box 1, UI Home Ec Records, IWA. 
even though ISC had the first program in the country while SUI had no such program. State legislators, likely under pressure from their constituents, disagreed with the board's proposal and passed legislation in 1913 allowing duplication of programs, including permitting a home economics program at SUI "to such an extent as will advance the educational interests of the state." ${ }^{20}$ Thus, three programs evolved on three campuses in ways unique to each institution's mission and vision.

At the end of the nineteenth century and in the early twentieth century, home economics was offered at more and more colleges, especially land-grant institutions. Two pieces of federal legislation in the 1910s gave the new field solid and lasting financial support. The Smith-Lever Act of 1914 provided funding for extension service work - for an agent to serve as a liaison between the scientific studies at a college and the people who could use the information. Many people benefited from extension service work. As Dorothy Schwieder has demonstrated, home economics extension service programs provided tangible connections, and education, for rural farm women. ${ }^{21}$ For many home economics programs, extension work provided the bulk of their revenue (income generated to support the program), a strength for nearly half a century, until research was valued as much as, if not more than, service. The Smith-Hughes Vocational Act of 1917 provided funding for teacher training, but it proved to be a double-edged sword: home economics education would be funded, but the very act of casting home economics purely as a vocation had a deleterious effect. Seen in this light, home economics was, Holt argues, stigmatized "as education for the lower classes and disadvantaged, not a discipline that could open up any number of work opportunities and lead to home betterment for girls of all socioeconomic groups." ${ }^{22}$

20. Report to Peat Marwick Main \& Company from the University of Iowa, 1989, p. 28, box 3, UI Home Ec Records, IWA.

21. Dorothy Schwieder, "The Iowa State College Cooperative Extension Service through Two World Wars," Agricultural History 64 (1990), 219-30. See also Edmund de S. Brunner and E. Hsin Pao Yang, Rural America and the Extension Service: A History and Critique of the Cooperative Agricultural and Home Economics Extension Service (New York, 1949).

22. Holt, Linoleum, Better Babies \& The Modern Farm Woman, 158. 
A combination of world events and federal funding initiatives continued to shape home economics in Iowa and nationally. The 1925 Purnell Act expanded extension services, particularly at research stations. The George-Reed Act of 1929 (and its successors in 1934 and 1936) included specific appropriations for home economics. The final extension, the George-Barton Act of 1946, further developed the place of home economics in vocational education. This and other federal legislation benefited home economics programs, providing sources of income. The benefits also went the other way, as demonstrated by the National School Lunch Act of 1946, when the government benefited from the knowledge of home economists who provided invaluable advice on nutritious, balanced, and economical foods to feed to schoolchildren. ${ }^{23}$

Home economists met the challenges of feeding a family during war and economic depression, particularly through extension work. During both world wars, extension service work emphasized conservation through canning, pickling, baking, and food substitutions. ${ }^{24}$ Iowa families were encouraged to increase production of corn and pork while decreasing consumption. Through menus emphasizing alternative foods, the goal was met. The federal government also created the Bureau of Home Economics in 1915, which contributed significantly to the war effort. ${ }^{25}$ The Great Depression was another moment of challenge and triumph for home economics. The value of extension

23. Eppright and Ferguson, A Century of Home Economics at Iowa State University, 73, 93, 102-3, 163.

24. On cooking challenges and solutions during these times, see Rae Katherine Eighmey, Food Will Win the War: Minnesota Crops, Cooks, and Conservation during World War I (St. Paul, MN, 2010); Harvey Levenstein, Paradox of Plenty: A Social History of Eating in Modern America (Berkeley, CA, 2003), esp. chaps. 4-6; Mary Drake McFeely, Can She Bake a Cherry Pie?: American Women and the Kitchen in the Twentieth Century (Amherst, MA, 2000), esp. chaps. 3-5; Harvey A. Levenstein, Revolution at the Table: The Transformation of the American Diet (Berkeley, CA, 2003), esp. chap. 11. On these processes more generally and historically, see Sue Shephard, Pickled, Potted, and Canned: How the Art and Science of Food Preserving Changed the World (New York, 2000).

25. For examples of home economics work during and after World War I, see Joan L. Sullivan, "In Pursuit of Legitimacy: Home Economists and the Hoover Apron in World War I," Dress 26 (1999), 31-46; and Paul V. Betters, The Bureau of Home Economics: Its History, Activities and Organization (Washington, DC, 1930). 
work, coupled with "radio homemakers," reinforced the value of home economics for Iowa residents as well as students. ${ }^{26}$

On the other hand, after 1945, the public perception of home economics, as reinforced by junior and senior high school home economics classes, was that home economics was merely cooking and sewing, skills either so easy that everyone knew how to do them or so simple that college courses were viewed as unnecessary. ${ }^{27}$ "Through the years, the students who have chosen home economics as a major did so partly because their interests were in things of the house. But always there were some who had a vocational goal too," a letter to alumnae of the SUI home economics department noted in 1955. "In the 1920s and 1930s teaching and hospital dietetics were about the only possibilities; today business is taking all of the home economic-trained personnel it can find for department store work with apparel and furnishings, for magazine writing, for work with food distributors and their trade associations.." ${ }^{28}$ Even alumnae, then, needed to be brought up to date on what the future held for more recent graduates of their program, and their vision of home economics needed to be expanded beyond domestic confines.

THE 1960s AND 1970s were years of great flux for home economics. ${ }^{29}$ Earlier in the century home economics had created a

26. Nationally, there were radio programs ranging from the federally sponsored "Aunt Sammy on the Air" to Columbia Broadcasting's "Radio HomeMaker." In Iowa, Iowa State's "Homemakers' Half Hour" aired on WOI from 1925 to 1966, and KMA (Shenandoah) had radio homemakers on the air from 1925 to the late 1980s. Holt, Linoleum, Better Babies $\mathcal{E}$ the Modern Farm Woman, 62-63, 151-52; Eppright and Ferguson, A Century of Home Economics at Iowa State University, 241; Evelyn Birkby, Neighboring on the Air: Cooking with the KMA Radio Homemakers (Iowa City, 1991). On the value of education during the Great Depression, see Dorothy Schwieder, "Education and Change in the Lives of Iowa Farm Women, 1900-1940," Agricultural History 60 (1986), 200-215.

27. As Megan Elias and others have demonstrated, college home economics courses were not sewing and cooking. One might major in fabrics, textiles, and clothing, or food and nutrition, but one still needed core courses in calculus, physics, chemistry, biology, sociology, and psychology. Elias, Stir It Up, chap. 3. 28. Alumnae Letter, 2/26/1955, box 1, UI Home Ec Records, IWA.

29. See Elias, Stir It Up, esp. chaps. 3 and 4; and Margaret W. Rossiter, Women Scientists in America: Before Affirmative Action, 1940-1972 (Baltimore, 1995), chap. 8. Note: In the 1960s Iowa State College became Iowa State University 
"niche" field for women incorporating science, social science, and humanities within an interdisciplinary title. As historian Margaret Rossiter has demonstrated, home economics provided an academic haven for women who held doctorates in the biological and physical sciences but could not find jobs in those departments. Within home economics departments, given the multi-disciplinary nature of the field, those women and their expertise were welcomed with open arms. ${ }^{30}$ As women and men began to rethink "appropriate" roles for women, home economics appeared to many to negatively reinforce female stereotypes. In higher education, people began to question why female students were preponderantly in schools of education and home economics rather than in schools of business, the sciences, or other areas. Using language from the Civil Rights Act, in 1969 the Women's Equity Action League "filed complaints against more than three hundred colleges and universities, including every medical school in the nation," challenging their exclusion, or quota, of women. ${ }^{31}$

At the same time that people were working to expand collegiate and post-collegiate options for women, home economics programs on college campuses were suddenly flush with research opportunities and funding. ${ }^{32}$ The federal government, eager for success in myriad Great Society programs, poured research money into programs examining family relationships and child development (Head Start), gerontology (Medicare), and nutrition (AFDC). At almost the same time, universities were working to increase their status, important measures of which were the number of faculty holding Ph.D.s, grant money received to cover salaries, and the like. Newer hires, men and

(ISU); the State University of Iowa dropped "State" (UI); and Iowa State Teachers College became the University of Northern Iowa (UNI).

30. See Rossiter, Women Scientists to 1940, esp. chap. 7; and Rossiter, Women Scientists, 1940-1972, esp. chap. 8.

31. Ruth Rosen, The World Split Open: How the Modern Women's Movement Changed America (New York, 2000), p. 89.

32. On changes in higher education, see Linda Eisenmann, Higher Education for Women in Postwar America, 1945-1965 (Baltimore, 2006); Hugh Davis Graham and Nancy Diamond, The Rise of American Research Universities: Elites and Challengers in the Postwar Era (Baltimore, 1997); and Clark Kerr, The Great Transformation in Higher Education, 1960-1980 (Albany, NY, 1991). 
women, tended to have doctoral degrees, while their more senior colleagues often did not. A 1988 self-study at ISU, for example, revealed that at least half of the associate professors whose highest degrees were master's or bachelor's degrees had received them in the 1940s and 1950s while almost all of the recent hires (1970s and 1980s) held doctorates. ${ }^{33}$ An additional way to prove legitimacy in home economics, some believed, was to increase the number of men in the department, particularly men who generated grants for research rather than relying on extension service or vocational funding.

Given these national changes and trends, the position of, and pressure on, home economics at each institution varied. Programs in home economics were populated almost exclusively by women, from faculty and staff to students. From 1960 to 1990, the proportion of female faculty in home economics remained extremely high, especially when compared to other departments. At UI, male faculty did not appear in the home economics department until the mid-1970s. Within that decade, the number of men doubled (to two) and the number of female faculty remained fairly constant. ${ }^{34}$ The student population was predominantly female as well, as an outside visitor to UI noted in 1983. "The student body profile in the Department of Home Economics is multi-cultural and diverse in age range. Although both males and females are enrolled in department programs the percentage of male students remains low. ${ }^{135}$ Historically, men could not gain admission to the home economics department, thus perpetuating gender stereotypes. This significant gender imbalance, coupled with very different areas of expertise within the same department, created a strong and cohesive community

33. AHEA Accreditation Self-Study - Appendix III Faculty, RS 12/14, folder 7, box 1, College of Family and Consumer Sciences Administrative Records (hereafter cited as CFCSA Records), University Archives, Iowa State University Library (hereafter cited as ISU Archives).

34. University of Iowa General Course Catalogs, University Archives, University of Iowa Libraries, Iowa City (hereafter cited as UI Archives), examined at fiveyear intervals, 1965-1990. This is a somewhat difficult example, as by 1985, some lines were cut or not renewed, and younger faculty who could do so went elsewhere, sensing (or knowing) that the department was not going to survive.

35. AHEA Site Visit Report, 1983, p. 18, box 1, UI Home Ec Records, IWA. 
internally, but within the larger academic institution it was easy to overlook or undervalue predominantly female colleges or programs. As universities became more interested in increasing female representation among faculty, home economics offered a department or program rich in women to counter the imbalance in other departments. At UI, for example, in 1989 "women faculty . . . comprise $6.1 \%$ of all women faculty in the College of Liberal Arts and $6.5 \%$ of all tenured women in the College. Without the faculty in Home Economics, the percentage of tenured faculty [university-wide] . . . who are women would decrease from $15.4 \%$ to $14.4 \% .^{\prime \prime 6}$

With the rise of second-wave feminism in the late 1960s and early 1970s, home economics came under fire for reinforcing traditional roles for women. Nowhere was this tension between feminism and this seemingly archaic field more evident than at the AHEA's annual meeting in 1971. "I gather from your literature and from the way home economics has functioned in this country that the main emphasis of your organization is to reinforce three primary areas: marriage, the family, and the issue of consumerism," invited speaker and feminist activist Robin Morgan said. "Now these three areas ... . are three of the primary areas that the radical women's movement is out to destroy. So one could say that as a radical feminist, I am here to destroy the enemy." Later, she noted that "many of you don't like that image of home economics and are trying to fight against it, and I want to talk about some concrete ways in which if you are sincere you can change that image and, more importantly, change women's lives." ${ }^{37}$

Morgan assumed that home economics taught women (mostly) to cook and sew, imposing a juvenile vision of home economics on college students, and overlooked what home economics did for its students and for the larger community. ${ }^{38}$ In

36. Report to Peat Marwick Main \& Co., p. 55.

37. "What Robin Morgan Said at Denver," Journal of Home Economics 65 (1973), 13. Telling of the level of discomfort Morgan's talk caused is the two-year lag between her speech and the formal account of it. With almost all other meeting matters, the Journal devoted extensive pages to resolutions, speeches, and more from the annual meeting in the very next issue. This lapse is unprecedented.

38. Elias, Stir It Up, esp. 146-52. 
fact, the AHEA had long advocated better day care and equal pay and, in a period of economic uncertainty, stressed nutritious and economic food preparation. ${ }^{39}$ Home economics was far from static, as a 1974 interview with Helen LeBaron Hilton, former dean of Home Economics at ISU, demonstrated. "Home economics is no longer focused on women," she noted. "It's because there is a blending of roles within the family, but there are still family problems and family needs. We have many more men coming into the field. . . There is a global erasing of the sex difference, too. . . . There is freedom that one can move in the direction of his interests and capabilities which is a very healthy frame of mind. ${ }^{\prime 40}$

To remain attractive to students in the 1970s and 1980s, programs in home economics needed to demonstrate their vitality to prospective students and faculty and campus administrators. First, they needed to be accredited by the national organization, the AHEA. ${ }^{41}$ This accreditation, good for 10 years, also required a mid-term five-year self-report. Additionally, some programs within home economics, such as nutrition or interior design, might also choose accreditation by their own professional organizations. Second, members of the departments needed to be "good citizens" of the university, which meant that faculty needed to serve on campuswide committees and bring in grant money to fund their research, graduate students, and salaries. Third, the departments needed to be well staffed by faculty

39. The AHEA, particularly its state and county branches, along with alumni associations, played a critical role in helping homemakers acclimate to the workforce in an age of rising divorces and more single mothers needing employment. On a more political bent, the AHEA affirmed its position in support of legalizing abortion, equal pay for equal work, and the ERA.

40. Helen LeBaron Hilton, interview with Eric Williams, 1974, typescript, folder 12, box 1, Helen LeBaron Hilton Papers, ISU Archives.

41. The AHEA changed its name in 1991, following recommendations emerging from the Scottsdale Conference, to the American Association of Family and Consumer Sciences (AAFCS). Because the professional organization was known as the AHEA throughout the period under consideration, it will be referred to as such. "Name Change and Scottsdale Meeting: Creating a Vision - The Profession for the Next Century, Working Conference, Final Report, 1991," box 222a, American Association of Family and Consumer Sciences Records, \#6578, Division of Rare and Manuscript Collections, Cornell University Library. 
dedicated to research or teaching, according to the demands of their particular institution. The departments at each institution met each of these standards, with local variation.

The AHEA began accrediting home economics programs, departments, and colleges in 1971. Different institutions made different choices regarding accreditation, not simply because of the work involved - a detailed self-study complete with voluminous documentation, given to outside evaluators to supplement their on-site visit, followed by their report, given to the AHEA and to the local campus for rebuttal. ${ }^{42}$ On most campuses, it took well over a year to amass and write up the necessary information, host the outside evaluators, and then respond to their report, indicating changes that would be in place for the mid-decade update. ISU's department discussed undertaking this process as early as $1976 .{ }^{43}$ In 1988 the college did seek accreditation. ${ }^{44}$ By contrast, UI's department took a different approach in 1975, when the faculty agreed not to pursue accreditation. "The faculty has discussed the topic of accreditation and agree with the President and the Dean of the College of Liberal Arts that accreditation is not needed to insure a high quality program. However, the faculty believes that the program may be endangered since other departments and colleges are in the accreditation process. They recommend, therefore, that the three Regents' institutions be accredited at the same time." ${ }^{\prime 5}$ The deferral in no way discounted the value of such work. In 1982, when the department sought accreditation, its self-evaluation highlighted ways it was exceptional. "The most obvious difference between Home Economics and other units [in Liberal Arts] is that the department of home economics received almost all of

42. For more on this process, see Linda Redmann Mahrer, "Specialized Accreditation of Home Economics: Historical Development and Present Status" (Ph.D. diss., University of Arizona, 1980).

43. College of Family and Consumer Sciences Minutes, 9/1/1976, RS 12/7/3, folder 30, box 1, ISU Archives.

44. For documentation of the 1988 accreditation, see RS 12/1/4, folders 4-7, box 1, CFCSA Records.

45. Self-Study and Departmental Analysis Report for Departmental Review, University of Iowa Department of Home Economics, 1975, p. 6, box 3, UI Home Ec Records, IWA. 
its income from the General Fund (State)." ${ }^{46}$ In this regard, the department differed significantly from the home economics programs at ISU and UNI, which derived a significant portion of their revenue from federal and state grants for extension work and vocational education. ${ }^{47}$

Much of the money that came to these universities through the home economics departments came through extension service, particularly at ISU. As important as this money was, however, money garnered through service was not regarded the same, campuswide, as money funding research. The advantage here accrued to ISU, where faculty, aided by graduate students, could conduct research as well as teach, with specific people set aside to do extension work. ${ }^{48}$ In particular, as institutions became more concerned with their profile, the emphasis on outside funding for research purposes became paramount.

Each home economics program in Iowa completed a selfassessment in the 1980s, either as part of the AHEA accreditation process or because of institutional mandate. The conclusions at each school were consistent with that university's larger academic goals. ISU's home economics program had many majors each year and performed a great deal of community service. One question raised by ISU's self-assessment was whether public service was trumping teaching. ${ }^{49}$ Limited evidence suggests that UNI's faculty accomplished a great deal with their limited resources, and by dint of their teaching load spent much of their time training students as future educators rather than conducting research. ${ }^{50}$ At UI, the home economics department was one of

46. Self-Evaluation Report for Accreditation by the American Home Economics Association, 1982, vol. 1, pp. 5-6, box 1, UI Home Ec Records, IWA.

47. No comparable documents regarding AHEA accreditation were found in UNI's archives.

48. Self-evaluation at UI, in preparation for AHEA accreditation, notes the discrepancy between state institutions. "The lack of a Ph.D. program and regularly funded teaching assistants has resulted in heavy teaching loads, and little consideration has been given to released time for direction of theses, honors projects, or directed studies." Self-Evaluation Report for Accreditation by the American Home Economics Association, 1982, vol. 2, box 1, UI Home Ec Records, IWA.

49. On this point, see AHEA Accreditation Self-Study - Appendix II, RS 12/1/4, folder 6, box 1, CFCSA Records.

50. See UNI Course Catalogs, 1970-1995, UNI Archives. 
only a few units not to offer a doctorate (which meant no gradate students as teaching or laboratory assistants). Additionally, it was one of only a few units within the College of Liberal Arts not to offer any general education courses or service any liberal arts students other than its own. Non-majors who benefited from the department's course offerings were not from Liberal Arts, where reciprocity and contributing to general education were valued; instead, they came from the medical and dental schools, social work, and education. ${ }^{51}$

An additional pressure on faculty was their terminal degree: Did they possess a doctorate or a master's and in what field? For faculty in interior design or fiber arts, for example, a Masters of Fine Arts was the appropriate terminal degree; but that did not look good, comparatively, across campus to other departments. This was particularly true at UI, where the home economics department was embedded within the College of Liberal Arts rather than its own college (as at UNI and ISU). Both ISU and UI strove to become nationally recognized (and ranked) institutions, which put increasing emphasis on external funding for research and on faculty with doctorates, which inadvertently penalized the home economics programs. In the mid-1980s UI began to emphasize doctorates as the appropriate terminal degree for its faculty. That emphasis, coupled with more research and its concomitant (external) funding, would raise the university's profile. Early in the decade, a self-evaluation noted that "the chair has communicated the necessity of the terminal degree to faculty members." ${ }^{\prime 2}$ Further, the report concluded that the "percentage of faculty with the terminal degree [other than Ph.D.] is higher than for most home economics units across the country. There continues to be a shortage of home economists with doctorates and a high demand for personnel to teach at colleges and universities." ${ }^{5}$

At the same time, the UI provost would not commit to funding lines within the department of home economics, so that the

51. Self-Evaluation Report for Accreditation by the AHEA, 1982, vol. 1, pp. 5-6, 27, box 1, UI Home Ec Records, IWA.

52. Ibid.

53. The comments conclude, "Salaries in the department are not competitive with those for home economists at comparable institutions." Ibid., vol. 2. 
faculty shrank due to a combination of retirements, unsuccessful tenure applications, and (younger) faculty opting to go elsewhere. A feeling of doom permeated the department. "Many faculty feel that the Department is assigned low prestige on the campus," a self-evaluation reported. "Such feelings are strengthened by a below average salary schedule, fairly high rates of turnover, replacements of departing or retiring faculty by new appointees commonly distinctly more junior, and an oldfashioned image of home economics as a field. ${ }^{\prime 54}$ Between 1983 and 1988, UI's home economics department sustained three retirements, five resignations, one negative tenure decision, one position terminated by the dean, and four positions made joint appointments with the College of Education. ${ }^{5}$

THE 1980s found the home economics programs at the three institutions in very different places, despite two common features: less money from the state and a report commissioned by the Regents to investigate duplication of services. ISU's home economics department spent the decade doing more with less and maintaining a high national profile. UI's department battled waning support internally and a diminution of its faculty. Again, the records at UNI do not reveal much about this period.

Home economics at ISU in the 1980s reaffirmed itself in myriad ways to the larger campus, the Regents, and the national organization. The department conducted a self-study in preparation for AHEA accreditation. Both the self-study and the accreditation itself were positive: the outside evaluators were highly satisfied with ISU.$^{56}$ On campus, the college grappled with how to strengthen and reach its goals in the "financial situation." Declining enrollments and pressures in the colleges of education and home economics placed pressure on the Department of Home Economics Education. "It is necessary," department meeting minutes in 1986 read, "that we 'regroup' or 'rejuvenate' in

54. Ibid.

55. Interim Accreditation Report to the Council for Professional Development, AHEA, 1988, p. 20, box 1, UI Home Ec Records, IWA.

56 . For the accreditation process and reports, see RS 12/1/4, folders 4-9, box 1 , and folders 1-9, box 2, CFCSA Records. 
order that we can assume responsibility that may differ sharply from what we have been doing the last several years." ${ }^{57}$ The only niggling question for the department was whether home economics education and home economics studies should merge, and, if so, what the new name should be. ${ }^{58}$

The Iowa Board of Regents, however, threw a wrench into the smooth operation of the school and the accreditation process when they forced the school's hand, deciding that the moniker "home economics" was no longer appropriate. Two Regents, both women, asked ISU president Gordon Eaton about the possibility of changing the name. At the board's October 1986 quarterly meeting, Regent June Murphy "stated that she had asked the same question [about changing the name] years ago and was shot down. She said a name change was a way of changing perception." At the following meeting, Regent Peg Anderson "stated that the board frequently gets requests for approval of a name change, and she wanted to know when they were going to change the name of the College of Home Economics because she believe[d] the name is a disadvantage. She stated that she has raised the question for each of her six years on the board, but there has been no effort to do anything about it." ${ }^{59}$

With this (strong) suggestion from the Board of Regents, ISU accelerated and reoriented the discussion of whether to change the name. Many other home economics programs across the country had engaged in similar discussions, so precedents for name and process existed. As the school had been considering such action, the top-down decision simply telescoped the process. Putting a positive spin on it, a subsequent self-study viewed the emerging consensus name "Family and Consumer Science" as "an effort to keep a more contemporary representation of college programs and not a new direction. The primary goal of avoiding divisiveness in the process of the name search

57. College of Family and Consumer Sciences, Department of Family and Consumer Science Education Minutes, 1/13/1986, 3/3/1986, RS 12/7/3, folder 4, box 2, ISU Archives.

58. See, for example, minutes from the $9 / 15 / 1996$ and 10/13/1996 meetings, ibid., folder 5, box 2 .

59. Iowa State Board of Regents Minutes, 10/15/1986, 2/18-19/1987, RS 01, ISU Archives. 
was fully accomplished." ${ }^{60}$ Those departments that had also been contemplating changing their name, such as Home Economics Education, shelved their discussions until the school name was determined, and then largely followed suit, using the same name for their departments when necessary. ${ }^{61}$

Home economics at UI on the other hand, faced more serious challenges in the 1980s. The sense of being asked to do more with less permeated the department even before the budget crunch of the mid-1980s. In August 1986, the dean of liberal arts at UI asked a committee to review the home economics department. The committee, composed of faculty in the College of Liberal Arts and one person external to the Iowa system, was, with one exception, all male. In its report, the review committee noted the social and cultural changes affecting the American family and, by extension, the field of home economics. As a discipline not rooted in "the bedrock of traditional liberal arts, nor ... . perceived as being potentially socially utile ... it is subject to social scrutiny, and to concomitant misapprehension and stereotyping." ${ }^{62}$ As

60. "Recognizing the need to study options of name, the Faculty Advisory Board had been asked earlier in the year to identify a subcommittee to propose a process for: reviewing experiences at other schools for surveying students, faculty, alumni and other clientele; for identifying a calendar for arriving at an appropriate solution to the question; and to recommend the composition of representation for the review committee." AHEA Accreditation Self-Study Appendix II, folder 6, box 1, College of Family and Consumer Sciences Administrative Records, ISU Archives. At its April 22-23, 1987, meeting, the Board of Regents approved the name change. The "university went through a consensus process for identifying a new name for the college. The result of the suggestion from faculty, and a preference poll concluded with the new name 'College of Family and Consumer Science.' It was hoped that this new name would enhance opportunities for greater fulfillment of the college's mission." President Eaton commented to the Regents that there was "a rather rapid convergence on the recommended name." Iowa State Board of Regents Minutes, 4/22-23/ 1987, RS 01, ISU Archives.

61. At its March 2, 1987, department meeting, home economics education chose to suspend its discussion until the college's new name was determined. With more discussion collegewide, but no new name yet chosen, the consensus at the April 13 meeting was to continue discussion. Finally, at the May 4 meeting, "after considerable discussion, faculty decided to table the decision to change the name of the department at this point in time." College of Family and Consumer Sciences, Department of Family and Consumer Sciences Education Minutes, RS 12/7/3, folder 5, box 2, ISU Archives.

62. This is perhaps one of the few time home economics was dismissed for not being "socially useful"; usually, the criticism of the field was that it was too 
reflected in recent name changes elsewhere, home economics, reviewers believed, might be suffering an identity crisis. The diverse nature of the field, "bringing together economists, social scientists, artists, aestheticians and others," made it hard to categorize or detect a unity of purpose so essential to other disciplines seeking to redefine themselves and appear relevant. Finally, the professional dimension of some programs, including dietetics and interior design, an anathema in the liberal arts, made some reviewers wonder if occupational training was driving the academic discipline, or vice versa. This last charge is puzzling, given that two of the five reviewers were housed in disciplines that defined themselves as training grounds for professions - social work and journalism and mass communication.

In conclusion, the committee reported, "The late 1980s are awkward and uncomfortable times for the field of home economics. . . . Home Economics is experiencing something akin to an identity crisis. The field displays extreme intellectual divisions, a professional component, unusual organization and other features which make the implementation of an efficient and effective academic curriculum challenging. . . . Meanwhile, the economic problems encountered by the university and the rigorous academic standards for promotion and tenure at the University of Iowa have added some particularly thorny problems to the packed agenda of the Department of Home Economics." Ultimately, the report lauded the department's primary strength teaching - and weakness - research — and suggested "improvements" without articulating how those might be made. ${ }^{63}$

If the review had been conducted because the dean was unsure whether home economics was properly placed in Liberal Arts, or was looking for an excuse to get rid of the department altogether, by some accounts external reviewer Urie Bronfenbrenner gave him what he was looking for. A professor in Cornell University's Department of Family Studies and Human Development, within the College of Human Ecology, Bronfenbrenner's inclusion on the committee - and his impartiality -

useful and not academic enough. Report of the Review Committee for the Department of Home Economics, The University of Iowa, 1987, p. 2, box 3, UI Home Ec Records, IWA.

63. Ibid., pp. 3, 4, 11-19. 
were questioned by some department members. ${ }^{64}$ His comments were, in fact, unambiguous, although they raised issues larger than the department at UI and the questions at hand. "My first and fairly firm conclusion," Bronfenbrenner wrote to Dean Gerhard Loewenberg, "is that neither the present state of Home Economics as a discipline, nor the present-day role of a College of Liberal Arts at a major university justifies the continuation of Home Economics as a separate department with its present composition and curriculum. At the same time, I believe that the existence of such a department within your college provides you with a rare and risky opportunity to pioneer by introducing a new essential but missing element in the Liberal Arts curriculum and in general education as a whole." ${ }^{165}$ Unfortunately, Bronfenbrenner's conclusion advocating home economics got lost in the hubbub surrounding his visit.

In the university's reallocation plan, implemented in October 1988 to deal with budget cuts in fiscal years 1985-1988, the administration decided to phase out dietetics and interior design options within the home economics major, which accelerated some retirements and hastened some resignations. Further, a 1987-88 request for a line in fiber arts, recommended by the department, was not put forward by the dean to the provost; the dean raised the possibility of advancing the request the following

64. "Both Carolyn [chair] and members of the Executive Committee raised the issue of his being able to review a program like ours. The Executive Committee was assured by the dean that Bronfenbrenner would be asked if he felt qualified to look at the entire program and department. Either he was not asked the question or his interest in an expense paid trip to visit his grandson was stronger than his integrity. . . . The Department submitted several names of qualified home economists that were not considered for nebulous reasons." Sara to Alice, Richard, Ei Soon and All of Us, 4/6/1987, folder: Response of faculty to review committee report, box 3, UI Home Ec Records, IWA; Report of the Review Committee for the Department of Home Economics, 1987, box 3, UI Home Ec Records, IWA.

65. Bronfenbrenner began his letter to Dean Loewenberg with "a disclaimer. Although I have for many years held an appointment in a College of Home Economics, and have considerable respect - even affection - for the accomplishments of that profession ... I cannot speak as an 'insider.' Moreover, it is quite unlikely that any academic identified with home economics would share my views and recommendations." Urie Bronfenbrenner to Dean Loewenberg, 12/17/1986, folder: Report of the Review Committee for the Department of Home Economics, 1987, box 3, UI Home Ec Records, IWA. 
year but the budget crisis precluded that action. The problems for the department were, on the one hand, not unique: all units in the Iowa system were being challenged by the budget cuts. On the other hand, more than half of the home economics faculty were very junior and so had less clout, fewer connections, and lower campus profiles than faculty in other departments. ${ }^{66}$

Looking to its 75th anniversary in 1988-89, the department could envision its future as alternately bright — faculty received merit raises for submitting grant proposals - and bleak - it was difficult for fiber arts and textiles faculty to find outlets for their creative works, their equivalent of publication. Despite the difficulties outlined in the interim accreditation report for the AHEA and the decision to not fund new or replacement faculty, a letter from Liberal Arts College Dean Gerhard Loewenberg to the department chair was supportive. "The Department of Home Economics," he wrote, "serves the needs of students in other colleges at the University, as well as the interest of large numbers of students in our College. If it did not exist, it would have to be invented." ${ }^{67}$

And then came 1989, when the Board of Regents commissioned a study by Peat Marwick to investigate possible duplications at the three Regents institutions. Home economics was one of five programs scrutinized; the others were business, education, engineering, and journalism. ${ }^{68}$ Among the home economics faculty on the UI campus, the mood in the 75th year of the program's existence was grim. In a preemptive move, before the final report was released, the home economics faculty voluntarily requested permission to have the department's AHEA accreditation withdrawn. ${ }^{69}$ When questioned by the AHEA director of accreditation, the department chair was firm in reiterating the department's decision, and explained its intention. "Our 'fate' is

66. Interim Accreditation Report to the Council for Professional Development, AHEA, 1988, pp. 2-4, box 1, UI Home Ec Records, IWA.

67. Ibid., p. 18.

68. Two decades later, the report's findings resulted in a diminution of two (of 15 possible) programs - home economics at UI and engineering at UNI - at the three universities.

69. Carolyn Lara-Braud to Karl Weddle, 2/17/1989, folder: Voluntary consent to withdraw accreditation, 1989, box 1, UI Home Ec Records, IWA. 
in the hands of the Board of Regents, and our Dean will make no ongoing commitments to us until this matter is resolved," wrote the chair. "At a meeting [with the dean] he indicated that our department may be eliminated or we may be changed to a non-degree granting program. Even if we survive the Regent's Program Duplication Audit, we will still have the problem of non-support from the Dean of the College. He has also informed us that if we are continued, we will have to change our name because he finds Home Economics unacceptable."

An initial assessment of the three programs, and UI's in particular, was positive. Addressing the investigators' initial charge, the analysts concluded that "there was no unnecessary duplication in Home Economics." The analysis addressed the strengths and weaknesses of each program, using data provided by the administration, faculty, students, and the departments to arrive at its conclusions. Whether the recommendations in the report were followed by the Regents was a different story altogether, and not the province of the assessment. Each of the three home economics programs had already implemented some costsaving measures in light of the budget cuts, and each serviced a different population with different needs, from UNI's regional catchment area to ISU's national and international student body. "It appears that the programs do not duplicate unnecessarily and this will not likely change. . . Regional enrollment as well as different student needs are met with the different programs," the team noted. In its first section, the report concluded that "even if the smaller programs were eliminated, the net savings for the universities would be quite small." ${ }^{71}$

70. The letter also discussed other problems, ranging from lack of support to retirements. The "only qualified member" to teach some core courses resigned; there was a negative tenure review; the dean pulled a faculty line because of the "precarious position" of home economics at UI; a permanent faculty line would be lost in spring 1989 following a mandatory retirement; a visiting faculty appointment for the previous three years would not be renewed; and the department had received no new lines in the previous five years. Carolyn Lara-Braud to Karl Weddle, 3/20/1989, folder: Voluntary consent to withdraw accreditation, 1989, box 1, UI Home Ec Records, IWA.

71. "Analysis of Home Economics Programs at Iowa State University, State University of Iowa and University of Northern Iowa," 1989, pp. 2, 13, box 3, UI Home Ec Records, IWA. The analysis was conducted by Dr. Leah Bailey, dean 
In its final report on program duplication, however, Peat Marwick focused less on cost savings and more on ways to strengthen Iowa's system of higher education. "There are insufficient resources and student demands to support broad-based, quality home economics education programs at the Regents Institutions as currently configured. Given the respective missions of the three Regents universities, ISU is the most appropriate place to offer a premier program in Home Economics." The document the Regents received suggested dismantling UI's department, even as the report "acknowledged the University's continual efforts to downsize the department and its continued viability" and noted that its fiber arts and design program was "unique among the Regents institutions." The final report also recommended that the department at UNI should be dissolved, given the program's uneven quality at undergraduate and graduate levels. ${ }^{72}$

The essence of the final report, in regard to home economics at the three Regents institutions was this: "We [Peat Marwick], together with the external higher education consultants, believe that the College of Family and Consumer Science at ISU has the faculty in place to be a national leader in home economics." But even this premier program, the sole "survivor" in the final report's envisioned landscape, needed more work. "To attain such pre-eminence, however, the college needs to re-think its undergraduate specialties and degrees, sharpen its focus internally, and build collaborations externally to additional problems facing individuals and families."

It is unclear why the final report ignored several key points of interest in the initial analysis, especially that each of the programs served a different population and different needs. Numerous studies, especially at UNI, documented students as unwilling to pursue home economics as a major if it meant attending a different (farther from home) campus. Even more distressing, from the UI department's point of view, was that, ultimately, only half of

of the College of Home Economics at Ohio State University, and Dr. Karen Craig, dean of the College of Home Economics at the University of Nebraska.

72. "Final Peat Marwick Report on Program Duplication," 1989, pp. 50-51, box 3, UI Home Ec Records, IWA.

73. Ibid., p. 55. 
the recommendation in the final report was implemented: UNI's program remained open even as UI's was shut down.

The combination of the disastrous internal review in 198687, a changing discipline, increasingly rigorous standards for faculty, and the Peat Marwick report spelled the end of home economics at UI. Faculty variously retired, resigned, left Iowa, or moved into other departments, depending on their years in the system and status (tenured or not). The department was disbanded in the late 1980s, with the major formally phased out beginning with the class entering in the fall of 1989. The 1990 course catalog announced that the phase-out was "a result of action taken by the State Board of Regents." Further, "all instruction in home economics is scheduled to end May 31, 1992," so majors were advised to plan accordingly, perhaps postponing general education courses to take required home economics courses while they were still offered. ${ }^{74}$ Despite calls for curtailing the program at UNI, the department survives to this day, although its name has changed to reflect developments and changes in the field and it lost its graduate program.

ISU's home economics program also survived, already having faced several challenges of its own during the 1970s and 1980s. A master plan for the College of Family and Consumer Science's first two decades of the twenty-first century, written in 1998, began by recalling the history of the department. "Enrollment shifts [in the mid-1970s] were due in part to female students selecting career choices away from Family and Consumer Science fields to careers in the hard sciences, engineering and business." The 1980s saw the "time-consuming and somewhat agonizing task of changing the name of our college," followed by "the threat to dissolve the college" posed by the Peat Marwick study. ${ }^{76}$ The college did not dissolve (nor, realistically, was

74. University of Iowa General Course Catalog, 1990-1992, 145, UI Archives.

75. In the early 1990s the department's name became Design, Family and Consumer Science. Today, it is the School of Applied Human Science in the College of Social and Behavior Sciences. On the first name change, see Senate Minutes and Dockets, box 13 [1], 1992, University of Northern Iowa Special Collections and University Archives, Cedar Falls.

76. Joan Herwig, "Voyage to the Future: Scenarios for the College of Family and Consumer Sciences, 2000-2020," 1999, pp. 12, 13, RS 12/4/18, folder 15, box 6, Joan Herwig Papers, ISU Archives. The "threat" to dissolve is a bit of 
that likely), but it did shrink, from eight departments to five, following the study's recommendations. ISU's college maintains its reputation as one of the strongest programs in family and consumer science in the country. The name of the school has changed again, most recently in 2004, but its strengths remain, including a national and international reputation and a well-trained faculty that successfully attracts grants to fund research. ${ }^{77}$

WHAT CAN WE LEARN from the creation, evolution, and survival of home economics at Iowa's Regents institutions? The same forces that encouraged the development of this new, academic, and science-based discipline supported its continuation. Those who saw women's roles as working inside or outside the home and wanted each woman to have the best tools to perform her chosen job to the best of her abilities valued home economics as a legitimate path for women's education. Students learned how to live healthfully, economically, and in aesthetically pleasing social and physical surroundings. People who opposed women's education or single-sex education for something they saw as innate rather than needing to be taught dismissed home economics as pigeonholing women into narrow roles.

narrative tension, or reflects a quick loss of memory. The program at ISU was the most stable, most flourishing, and least endangered in the Peat Marwick report, unless the report recommended eradication of home economics entirely in Iowa.

77. The impetus for the 2004 name change was, again, a budget crisis: the 2003 fiscal year budget was cut 2.5 percent, but the previous seven years had seen successive budget cuts, with a sustained loss of 23 percent over the preceding four years. The provost, charged with finding more ways to save money, recommended combining the colleges of Education and Family and Consumer Sciences (FACS) and using the $\$ 500,000-\$ 700,000$ in annual administrative savings to "enhance the high priority academic programs" offered in each school. Further, FACS had the second-lowest enrollment of any college at ISU, with 1,500 students (the veterinary college had the lowest enrollment). University Councils and Committees, Planning Committee for the Combination of the Colleges of Education and Family and Consumer Sciences, RS 8/6/177, folder 4, box 1, ISU Archives. The process of combining the colleges of Education and Family and Consumer Sciences was transparent, open, and methodical. Minutes from each of the working groups were posted online; forums were held on and off campus to reach students and alumni; and a timetable established at the beginning of the transition held. For more on this, see ibid. 
On college campuses, and especially at the University of Iowa, where the department was housed within the College of Liberal Arts, the lack of utility of home economics courses for other majors was seen by those already unhappy with its existence as reinforcing the problematic nature of the major. Because success breeds success, and support from administration is crucial, the program at ISU thrived while the program at UI flailed. Faculty at ISU also faced pressure in the 1980s to increase grants, extension work, and relationships with local entities, but they were aided by a culture of grant-driven research and the presence and assistance of graduate students who could expect to attain a doctorate. In contrast, administrative support for UI's department waned, even as the department sought accreditation and outside evaluation to improve the program. An already weakened department, it found it difficult to refute many of the charges in Peat Marwick's report on program duplication.

Home economics attracted female students, as it was intended to. On many campuses, through the 1950s (or later), male students could not enroll as majors, thus reinforcing the female stereotype of the discipline. Gender was implicit in, and perhaps a key consideration of, how home economics programs were evaluated and valued by the Board of Regents in the 1980s. Family and consumer science, by contrast, is not similarly bound by gender restrictions or public perception; many programs across the country, including ISU's, are seen as excellent preparation for medical or graduate school and have more than just token male representation in the student population. ${ }^{78}$

In examining the success and failure of home economics programs at other institutions, the authors of ISU's vision for the twenty-first century aptly summarized reasons for failure. "In recent dissolutions and mergers of colleges of Family and Consumer Science . . . four principal factors appear to be at work: budget cutting, change of leadership that makes the college vulnerable, the merging of a weaker unit with a stronger, [and] lack of commitment to the mission that holds them together." ${ }^{\prime 79}$ The study cited myriad programs as examples, with

78. Other names for family and consumer science departments include human ecology, human sciences, and human development.

79. Herwig, "Voyages to the Future," 21. 
one or more of these factors to explain their current status. This paradigm works well for the Iowa institutions. At UNI, budget cuts coupled with the Peat Marwick report were the biggest threats to the program. Through adroit maneuvering, including making the program relevant to the mission of the university, home economics survived (minus its graduate program). At UI, the budget was the final straw, heaped as it was on top of vulnerability in the form of lack of support from administrators; a new, young department chair; and a department that many never saw as fitting in the larger mission of the College of Liberal Arts. At ISU, the budget pressures were present but not insurmountable. The school reorganized, eliminating three departments. Almost two decades passed between those changes and the combination of the Schools of Education and Family and Consumer Science (FACS); FACS may not have been a weak unit at ISU, but it was one of the smallest.

With similar economic pressures on state educational institutions today and a push for consolidation and efficiency, the success or failure of Iowa's home economics programs in the 1980s may offer some models for evolution and survival. The integrative model presented by family and consumer sciences, working in social, behavioral, biological, and physical sciences, manages to flourish, adapt, and survive and poses a model worthy of emulation for departments or programs under fire. 